\title{
Melonworm, Diaphania hyalinata Linnaeus (Insecta: Lepidoptera: Pyralidae) $)^{1}$
}

John L. Capinera ${ }^{2}$

\section{Distribution}

Melonworm, Diaphania hyalinata Linnaeus, occurs throughout most of Central and South America and the Caribbean. The United States is the northern limit of its permanent range, and wintertime occurrence generally is limited to south Florida and perhaps south Texas. Melonworm disperses northward annually. Its distribution during the summer months is principally the southeastern states, though occasionally it disperses north to New England and the Great Lakes region.

\section{Life Cycle and Description}

The melonworm can complete its life cycle in about 30 days. It is present throughout the year in southern Florida, where it is limited mostly by availability of host plants. It disperses northward annually, usually arriving in northern Florida in June and other southeastern states in July, where no more than three generations normally occur before cold weather kills the host plants.

\section{Egg}

Melonworm moths deposit oval, flattened eggs in small clusters, averaging two to six eggs per egg mass. Apparently they are deposited at night on buds, stems, and the underside of leaves. Initially they are white or greenish, but soon become yellow in color. They measure about $0.7 \mathrm{~mm}$ in length and $0.6 \mathrm{~mm}$ in width. Hatching occurs after three to four days.

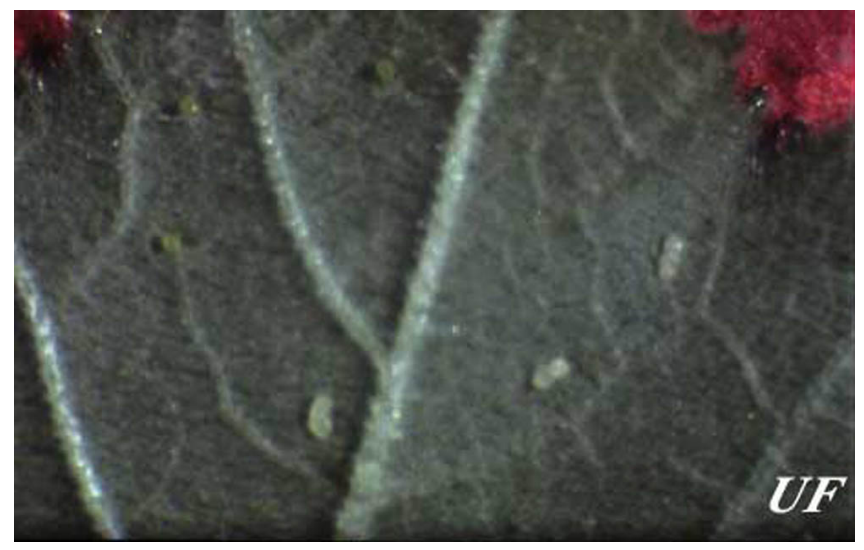

Figure 1. Eggs of melonworm, Diaphania hyalinata Linnaeus, on foliage. Credits: Rita Duncan, University of Florida

1. This document is EENY-163, one of a series of Featured Creatures from the Entomology and Nematology Department, Florida Cooperative Extension Service, Institute of Food and Agricultural Sciences, University of Florida. Published: October 2000. This document is also available on Featured Creatures Website at http://creatures.ifas.ufl.edu. Please visit the EDIS Website at http://edis.ifas.ufl.edu.

2. John L. Capinera, professor/chairman, Department of Entomology and Nematology, University of Florida, Gainesville, FL.

The Institute of Food and Agricultural Sciences is an equal opportunity/affirmative action employer authorized to provide research, educational information and other services only to individuals and institutions that function without regard to race, color, sex, age, handicap, or national origin. For information on obtaining other extension publications, contact your county Cooperative Extension Service office. Florida Cooperative Extension Service/Institute of Food and Agricultural Sciences/University of Florida/Christine Taylor Waddill, Dean. 


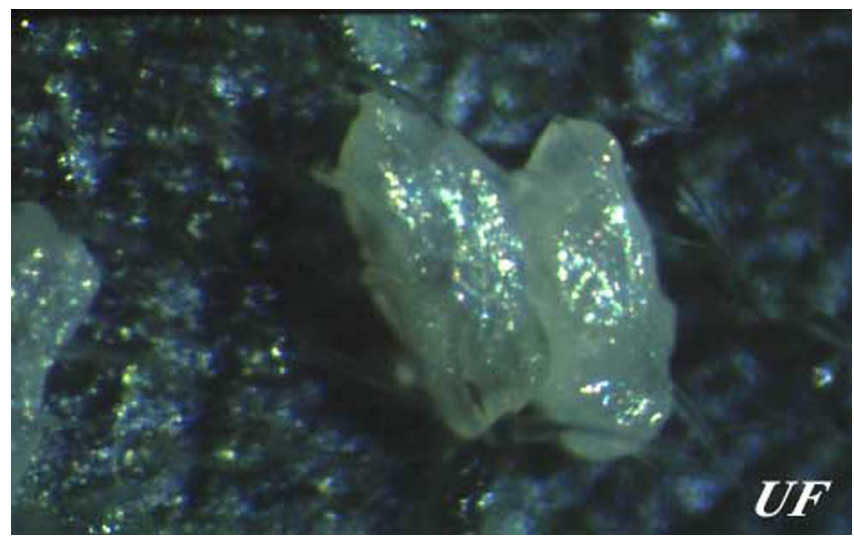

Figure 2. Closeup of eggs of melonworm, Diaphania hyalinata Linnaeus. Credits: Rita Duncan, University of Florida

\section{Larva}

There are five instars. Total larval development time is about 14 days, with mean (range) duration the instars about 2.2 (2-3), 2.2 (2-3), 2.0 (1-3), 2.0 (1-3), and 5.0 (3-8) days, respectively. Head capsule widths are about $0.22,0.37,0.62,1.04$, and $1.64 \mathrm{~mm}$, respectively (Smith et al. 1994). Larvae attain lengths of about 1.5, 2.6, 4.5, 10, and $16 \mathrm{~mm}$ in instars one through five, respectively. Newly hatch larvae are colorless, but by the second instar larvae assume a pale yellow-green color. They construct a loose silken structure under leaves which serves to shelter them during the daylight hours. In the fifth instar, larvae have two subdorsal white stripes extending the length of the body. The stripes fade or disappear just prior to pupation, but they are the most distinctive characteristic of the larvae.

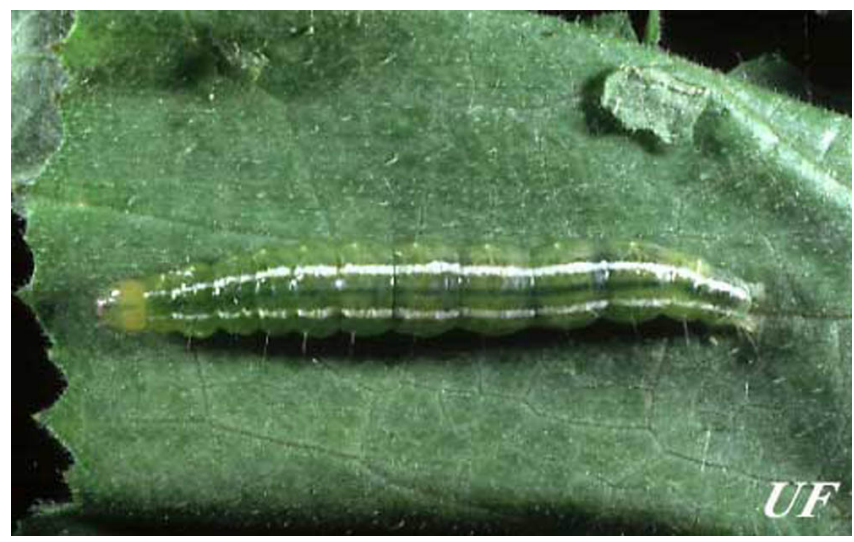

Figure 3. Mature larva of melonworm, Diaphania hyalinata Linnaeus. Credits: John L. Capinera, University of Florida

\section{Pupa}

Prior to pupation, larvae spin a loose cocoon on the host plant, often folding a section of the leaf for added shelter. The pupa is 12 to $15 \mathrm{~mm}$ in length, about 3 to $4 \mathrm{~mm}$ in width, and fairly pointed at each end. It is light to dark brown in color. The pupal stage persists for nine to 10 days.

\section{Adult}

The moth's wingspan is about $2.5 \mathrm{~cm}$. The wings are pearly white centrally, and slightly iridescent, but are edged with a broad band of dark brown. Moths frequently display brushy hairpencils at the tip of the abdomen when at rest. Melonworm moths remain in the crop during the daylight hours. While they are generally inactive during the day, they will fly short distances when disturbed. Smith (1911) provides a detailed account of melonworm biology.

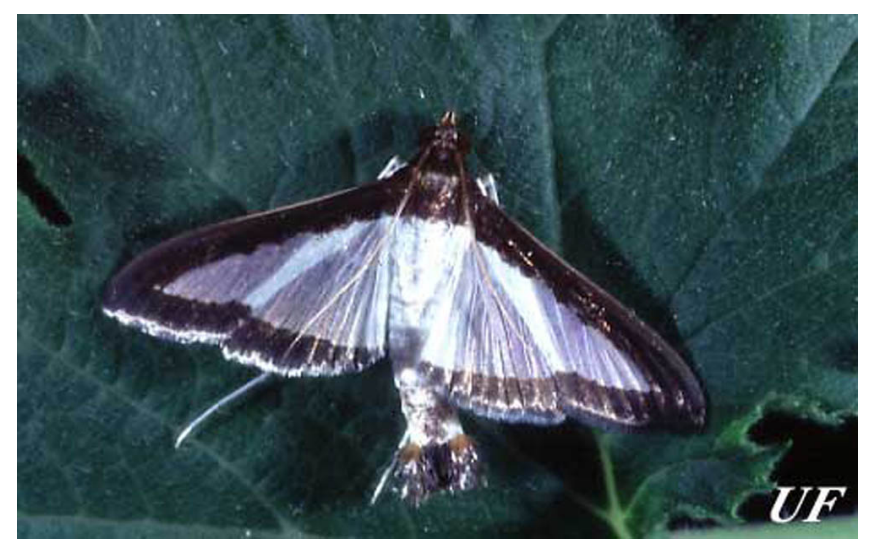

Figure 4. Adult melonworm moth, Diaphania hyalinata Linnaeus. Credits: John L. Capinera, University of Florida

\section{Damage}

Melonworm feeds principally on foliage, especially if foliage of a favored host plant such as summer or winter squash is available. Usually the leaf veins are left intact, resulting in lace-like plant remains. However, if the available foliage is exhausted, or the plant is a less preferred species such as cantaloupe, then the larva may feed on the surface of the fruit, or even burrow into the fruit. Growers sometimes refer to these insects as "rindworms" because they cause scars on the surface of melons. In a study of melonworm damage potential to summer squash conducted in south Florida, melonworm caused a $23 \%$ yield loss due to foliage damage 
(indirect loss) and a 9 to $10 \%$ yield reduction due to fruit damage (direct loss) (McSorley and Waddill 1982). Kelsheimer (1949) considered this insect to be the most important pest of cucurbits in Florida.

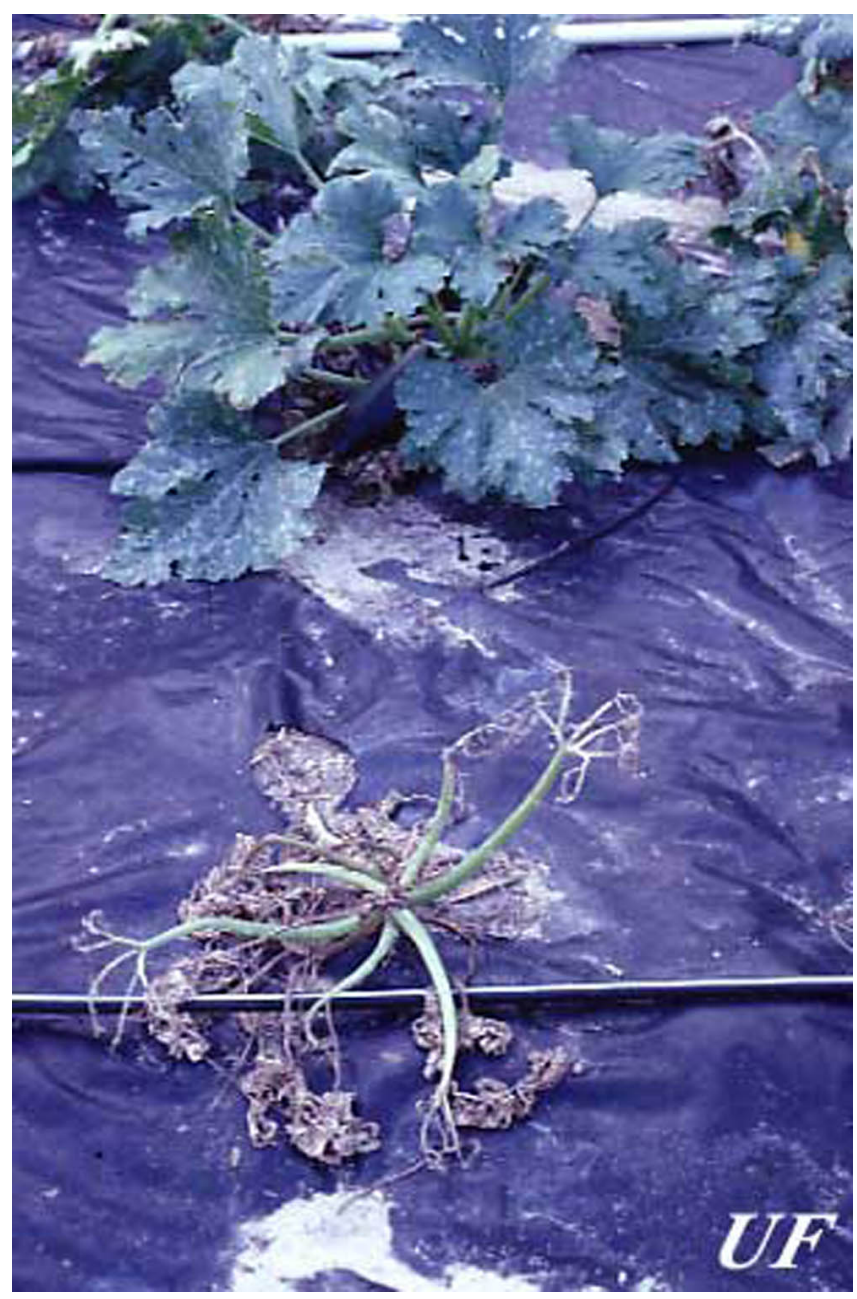

Figure 5. Defoliation of young squash plant by larvae of the melonworm, Diaphania hyalinata Linnaeus. Credits: John L. Capinera, University of Florida

\section{Natural Enemies}

Among the common natural enemies of melonworm are Apanteles sp., Hypomicrogaster diaphaniae (Muesebeck), Pristomerus spinator (Fabricius) (all Hymenoptera: Braconidae), Casinaria infesta (Cresson), Temelucha sp. (both Hymenoptera: Ichneumonidae), and undetermined trichogrammatids (Hymenoptera:

Trichogrammatidae) (Pena et al. 1987b, Capinera 1994). However, additional species parasitized melonworm, including Gambrus ultimus (Cresson), Agathis texana (Cresson) (both Hymenoptera: Ichneumonidae) and an undetermined fly
(Hymenoptera: Tachinidae). The tachinids known from melonworm are Nemorilla pyste (Walker) and Stomatodexia cothurnata (Wiedemann). Studies conducted in Puerto Rico (Medina-Gaud et al. 1989) reported levels of parasitism reaching $24 \%$.

Generalist predators such as Calosoma spp. and Harpalus (both Coleoptera: Carabidae), the soldier beetle Chauliognathus pennsylvanicus DeGeer (Coleoptera: Cantharidae), and the red imported fire ant Solanopsis invicta Buren (Hymenoptera: Formicidae) have also been reported to be mortality factors.

\section{Management}

\section{Sampling}

Pheromone production by female moths peaks at about sunset (Valles and Capinera 1992). The sex pheromone has been identified (Raina et al. 1986) but is not available commercially. Moths are not attracted to light traps. Therefore, checking plants for early stages of leaf damage and the presence of arvae are the most effective ways to monitor crops.

\section{Insecticides}

Historically, melonworm was considered to be a very damaging pest, but because it feeds preferentially on foliage it is easy to control with a variety of insecticides. In temperate areas, and especially in commercial vegetable production areas, it is treated as only a minor pest. In insecticide-free cucurbit production and in home gardens, melonworm can cause serious damage.

Pollinators, particularly bees, are very important in cucurbit production, and insecticide application can interfere with pollination by killing honeybees. If insecticides are to be applied when blossoms are present, it is advisable to use insecticides with little residual activity, and to apply insecticides late in the day, when bee activity is minimal.

See the Insect Management Guide for Vegetables.

\section{Biological Control}

In addition to chemical insecticides, Bacillus thuringiensis is commonly recommended for suppression. The entomopathogenic nematode 
Steinernema carpocapsae provides only moderate suppression because the nematodes do not survive long on the foliage, where larvae are found resting and feeding (Shannag and Capinera 1995).

\section{Cultural Practices}

Row covers can be used effectively to exclude melonworm adults (Webb and Linda 1992). Intercropping of corn and beans with squash was shown to reduce damage by melonworm (Letourneau 1986). Since melonworm prefers squash to most other cucurbits, trap cropping has been suggested, and of course destruction of crop residue which may contain melonworm pupae is recommended (Smith 1911). Early plantings, except in tropical areas where melonworm overwinters, often escape serious damage.

\section{Selected References}

Capinera, J.L. 1994. Pickleworm and melonworm. Pages 140-145 in D. Rosen, F.D. Bennett, and J.L. Capinera (eds.). Pest Management in the Subtropics: Biological Control -- A Florida Perspective. Intercept, Andover, United Kingdom.

Capinera, J.L. 2001. Handbook of Vegetable Pests. Academic Press, San Diego. 729 pp.

Kelsheimer, E.G. 1949. Control of insect pests of cucumber and squash. Florida Agricultural Experiment Station Bulletin 465. 15 pp.

Letourneau, D.K. 1986. Associational resistance in squash monocultures and polycultures in tropical Mexico. Environmental Entomologist 15:285-292.

Medina-Gaud, S., E. Abreu, F. Gallardo, and R.A. Franqui. 1989. Natural enemies of the melonworm, Diaphania hyalinata L. (Lepidoptera: Pyralidae) in Puerto Rico. J. Agric. Univ. Puerto Rico 73:313-320.

McSorley, R. and V.H. Waddill. 1982. Partitioning yield loss on yellow squash into nematode and insect components. Journal of Nematology 14:110-118.

Pena, J.E., V.H. Waddill, and K.D. Elsey. 1987a. Population dynamics of the pickleworm and the melonworm (Lepidoptera: Pyralidae) in Florida. Environmental Entomologist 16:1057-1061.

Pena, J.E., V.H. Waddill, and K.D. Elsey. 1987b. Survey of native parasites of the pickleworm, Diaphania nitidalis Stoll, and melonworm, Diaphania hyalinata (L.) (Lepidoptera: Pyralidae), in southern and central Florida. Environmental Entomologist 16:1062-1066.

Raina, A.K., J.A. Klun, M. Schwarz, A. Day, B.A. Leonhardt, and L.W. Douglass. 1986. Female sex pheromone of the melonworm, Diaphania hyalinata (Lepidoptera: Pyralidae), and analysis of male responses to pheromone in a flight tunnel. Journal of Chemical Ecology 12:229-237.

Shannag, H.K. and J.L. Capinera. 1995. Evaluation of entomopathogenic nematode species for the control of melonworm (Lepidoptera: Pyralidae). Environmental Entomologist 24:143-148.

Smith, H.A., J.L. Capinera, J.E. Pena, and B. Linbo-Terhaar. 1994. Parasitism of pickleworm and melonworm (Lepidoptera: Pyralidae) by Cardiochiles diaphaniae (Hymenoptera: Braconidae). Environmental Entomologist 23:1283-1293.

Smith, R.I. 1910. Insect enemies of cantaloupes, cucumbers and related plants. North Carolina Agricultural Experiment Station Bulletin 205. 40 pp.

Smith, R.I. 1911. Two important cantaloupe pests. North Carolina Agricultural Experiment Station Bulletin 214:101-146.

Valles, S.M., and J.L. Capinera. 1992. Periodicity of attraction of adult melonworm, Diaphania hyalinata. Florida Entomologist 75:390-392.

Webb, S.E. and S.B. Linda. 1992. Evaluation of spunbounded polyethylene row covers as a method of excluding insects and viruses affecting fall-grown squash in Florida. Journal of Economic Entomology 85:2344-2352. 